\title{
Creating Innovative E-Portfolios for Lifelong Learning and Evaluation: An Assessment Tool for Career Planning
}

\author{
Bob Barrett
}

\begin{abstract}
While many educational institutions struggle to find the perfect assessment to evaluate student content knowledge, they may lose sight of the next step - lifelong learning. This paper will focus on how the creation and implementation of e-Portfolios can help to prepare senior undergraduate students to design and realize future career pathways with the use of this electronic assessment tool. In particular, this paper will illustrate how one university has changed their focus in evaluating student learning in a strategic approach to incorporate a new type of "capstone" course for business undergraduate students. As a result, there are still students leaving educational institutions not fully prepared as to how to approach the job hunting process. This particular academic tool has been helpful for the instructor to evaluate the students' abilities and skills to apply content knowledge gained from the core business administration programs, as well as prepare students for their next career endeavor.
\end{abstract}

Index Terms-Assessment, e-portfolio, lifelong learning, and online learning.

\section{OVERVIEW OF DistANCE EDUCATION}

Distance education is filling a void in the many different working and family schedules for adult learners. Distance education is defined as "education that takes place independent of location, in contrast to education delivered solely in the classroom, and that may be independent of time as well [1]. ASTD, an education/training \& development professional organization, noted that "distance education can be characterized as an educational situation in which the instructor and students are separated by time, location, or both. Education or training courses can be delivered to remote locations via synchronous or asynchronous means of instruction [2]. As a result, more non-traditional students are taking advantage of online course offerings/programs.

Prior to this definition, the U.S. Government and Department of Education started to view the value of education and technology in a different light. They realized that technology was the tool to help facilitate learning, as well as prepare students for the workplace. As a result, in the early and mid-1990s, the U.S. Secretary of Education released the nation's first educational technology plan in 1996. The Plan was entitled, "Getting America's Students Ready for the $21^{\text {st }}$ Century: Meeting the Technology Literacy Challenge. While this plan was focused on elementary and secondary schools, it did provide a framework for educators on the post-secondary level to consider as they prepare future

Manuscript received February 10, 2012; revised March 20, 2012

B. Barrett is a professor in the School of Business at the American Public University, Charles Town, WV 25414 USA. (email: docjob00@msn..com). educators for work on the elementary and secondary school levels. The goals were:

- Goal 1: All students and teachers will have access to information technology in their classrooms, schools, communities, and homes.

- Goal 2: All teachers will use technology effective to help students achieve high academic standards.

- Goal 3: All students will have technology and information literacy skills.

- Goal 4: Research and evaluation will improve the next generation of technology applications for teaching and learning.

- Goal 5: Digital content and networked applications will transform teaching and learning. [3].

In 2006, 38 states in the United States have established state-led online learning programs, policies regulating online learning, or both. Also, 25 states have state-led online learning programs, and 18 states are home to a total of 147 virtual charter schools serving over 65,000 students [4]. In 2001, 56\% of traditional learning institutions offered distance learning programs. An additional $12 \%$ of schools stated they planned on adding distance learning programs to their curriculum within the next three years [5]. Thus, more secondary- and post-secondary level teachers will need to seek additional education in order to obtain and master quality online teaching skills and strategies. As a result, more universities are offering online education courses and teacher training in order to help recruit and hire more online instructors. Thus, there is a growing need to increase the number of online instructors to teach at many educational institutions.

\section{Demographics of OnLine LEARNING (Distance EDUCATION)}

As a result of changing economic factors and budgetary changes, many traditional teachers and students have started to move away from taking traditional on-ground classes, and opting for online courses. Thus, schools have seen an increase in their student populations, and now they are faced with the growing dilemma of lack of physical classroom space. Thus, the need for additional online courses has risen as a result of these ever-increasing student enrollments. Further, many traditional teachers have been considering or reconsidering the option of transitioning over to the online learning environment, as opposed to limiting their career possibilities solely to the on-ground teaching experiences. Finally, many current and potential instructors are seeking 
training in order to obtain proper online instruction to prepare them for online teaching.

Another factor affecting the change in learning demographics has been the onset of more learning technology. It has become available in many parts of the world, and a new type of student population has emerged. The traditional student image of higher learning has been somewhat limited in many countries, but given the impact of the Internet, this traditional "student body" has changed to online communities. In the field of business and management, educators have recognized the demographical changes of the student population. In a virtual environment, the student is not the same traditional student seen in classrooms in previous years, but rather one that reflects a vast array of cultural differences and needs that require educators to help build "new learning paths" towards the creation of virtual learning communities.

The number of students taking at least one online course continues to expand at a rate far in excess of the growth of overall higher education enrollments. The most recent estimate, for fall 2007, places this number at 3.94 million online students, an increase of 12.9 percent over fall 2006. The number of online students has more than doubled in the five years since the first Sloan survey on online learning. The growth from 1.6 million students taking at least one online course in fall 2002 to the 3.94 million for fall 2007 represents a compound annual growth rate of 19.7 percent. The overall higher education student body has grown at an annual rate of around 1.6 percent during this same period (from 16.6 million in Fall 2002 to 18.0 million for Fall 2007 Projections of Education Statistics to 2017, National Center for Education Statistics). As the following table illustrates, over one-fifth of all higher education students are now taking at least one online course.

Who are these 3.9 million students? The overwhelmingly majority (over 80 percent) are studying at the undergraduate level with only 14 percent taking graduate level courses and the remainder in some other for-credit course. Using survey results and figures from the most recent federal data (Digest of Education Statistics: 2007, National Center for Education Statistics) to compare enrollment patterns shows only slight variations in the proportions of students by education type. The proportion of undergraduates in online education (83.9 percent) is slightly below that of the total population of higher education students (85.6 percent) [6].

Since technology has provided a powerful infrastructure, the emerging technologies have allowed educational institutions, educators, and students to provide education on a much higher playing field - in a virtual learning environment. Consequently, the business world has also worked with technology in this venture to help assist educational institutions in becoming more modern and adaptive for change. As a result, these changes only signify to the educational and learning communities that technology recognizes a need for change - but do we, as educators, recognize the need for change completely? Finally, many educational institutions, as well as the corporate world, are focusing on the learning process and its impact on their organizational structure and employees.

In fact, many people are considering online learning to be a new academic endeavor, one must also consider the next step for college graduates - the world of work. In this regard, the corporate environment may differ from the academic setting; however, the need to learn and grow is equally important in the world of business and academia. While online learning has been focused more on the academic setting, many companies are learning that online learning has many benefits in the corporate/business environments. Thus, many companies and organizations are focusing on the "learning" element of their employees' daily work lives, as well as helping to build their knowledge management with a concentration on helping the organization learn from previous and current experiences. From the literature, we noted that "organizational learning involves the acquisition of new information and the ability to analyze that information creatively, learn from it, and apply that learning in useful ways." [7]. As organizations realize that there is a need to "capture" and "utilize" this type of learning, they also realize the need for the organization, as a whole, to concentrate on building up this learning element to include everyone in their respective organization, as well as setting up informal and formal learning center or circles. While organizations and communities view the impact of online learning in the U.S., we also have to look at how type of learning is impacting the world and our global capital.

Contextually, one can see a new, global branding of course management systems, which affects and supplements the needs of growing, virtual learning communities. As a result, educators need to reflect on the historical changes in distance learning in order to better understand how technology can enhance their virtual teaching - as well as helping them to adapt from their traditional "framework of teaching" into a more modern and culturally diversified way of teaching. Thus, this leads us to the next part of this paper's focus, an overview of what e-Portfolios are and how they are used.

\section{AN OVERVIEW OF E-PORTFOLIO: ROLE AND PURPOSE IN EVALUATING STUDENT'S WORK}

Electronic Portfolios (e-Portfolios) have been defined in many different ways in terms of how they are designed and developed, as well as implemented and evaluated. An e-Portfolio "functions like a file cabinet with file drawers and file folders. Students store personal, educational, career, skill assessment, non-academic/work experience, certification, and rewards information in their portfolios. The information placed in an ePorfolio is referred to as an artifact." [8]

While some academic institutions are quick to employ very extensive and developed e-Portfolio software systems, others educational organizations may want to consider their own creation and implementation of an e-Portfolio system (evaluative project). As a result, one can surmise that there are many different needs to be considered here in terms of determine how an e-Portfolio system/project can be used and eventually evaluated. In any event, it is ultimate role of the educational institution to determine if there is a need and how it can be met in terms of an e-Portfolio approach.

In order to understand why e-Portfolios are used, one needs to look at its role and purpose in today's learning environment. Can educational institutions evaluate a 
student's skills and ability, as well as help them prepare for potential career development opportunities? Many universities are turning towards the creation and implementation of e-Portfolios. These e-Portfolios serve several purposes, but the final outcome is whether the e-Portfolio itself can be seen as a true measure of what the student has been able to achieve - as well as serve as an indicator of their potential skills and abilities. Thus, the key goal of the e-Portfolio is to help highlight the student's ability to create a collection, selection, and reflection of their online works that best demonstrates their skills and abilities. One needs to look at the evaluative purpose of e-Portfolios.

\section{E-PortFolio ApPlicAtions IN THE ClASSROOM}

E-portfolios serve as a showcase of a collection of selected "created" academic achievements to demonstrate a student's writing and researching skills. It was noted that "the e-portfolio is not simply a personal home page with links to examples of work ... it is a network application that provides the author with administrative functions for managing and organizing work (files) created with different applications for controlling who can see the work and who can discuss the work (access) ... "[9]. The application of e-portfolios in the academic environment has been increasing over the decades. However, with the onset of the technological evolution, the use of computers in the academic setting has enabled many instructors, administrators, and staff members to create and implement a variety of educational applications. Rather than focusing on only one single final course project, the e-portfolio serves as a replacement for the final course project, as well as enhancement of the learning experience.

As each instructor or course designer prepares courses, they have to decide upon which type of portfolio is necessary to meet the course objectives. According to Greenberg (2004), there are three types of portfolios:

- Showcase e-portfolio - organization occurs after the work has been created.

- Structured e-portfolio - a predefined organization exists for work that is yet to be created.

- Learning e-portfolio - organization of the work evolves as the work is created. [10]

If we examine the use of e-Portfolios in terms of school accreditation, many educational institutions focus on the "showcase e-portfolio" approach. However, as more and more online schools begin to incorporate e-portfolios into their courses and programs, they are learning more towards structured e-portfolios. On the other hand, some colleges and universities are moving a step further to a more learner-centered approach and using learning e-portfolios.

In order to select one of these types of portfolio, the instructor needs to review the course objectives and determine what is the primary purpose for using an E-Portfolio in the course? According to a self-report survey of 51 Universities and Colleges, it was reported on the following primary and secondary purposes of E-portfolios. Listed below are the primary purposes of E-portfolios.

- Academic planning and advising (4\%)

- $\quad$ Student evaluation and grading $(24 \%)$

- Career and resume planning (16\%)
- $\quad$ Reflection (36\%)

- Institutional Assessment/Program Evaluations (8\%)

- Faculty Evaluation and Tenure (4\%)

- Other $(2 \%)$

- $\quad$ Not Available (6\%) [11]

Further, these are the secondary purposes of E-Portfolios.

- Academic planning and advising (25\%)

- $\quad$ Student evaluation and grading (14\%)

- Career and resume planning (43\%)

- $\quad$ Reflection (29\%)

- Institutional Assessment/Program Evaluations (47\%)

- $\quad$ Faculty Evaluation and Tenure (5\%) [12]

What role does the e-Portfolio serve in terms of career development for the student? After the turn of the century, many academic departments look towards the local and regional employers for answers to their curriculum questions - what do employers want and need. In specific, many educational institutions want to know what employers look for in graduates in terms of their qualities, characteristics, and skills. The National Association of Colleges and Employers Survey reported the following information about what was the Top 9 Qualities/Skills Employers Seek:

- Communication skills (Verbal \& written)

- Honesty/integrity

- Interpersonal skills (relates well to others)

- $\quad$ Strong work ethic

- Analytical skills

- Flexibility/adaptability

- Computer skills

- Organizational skills

- Motivation/initiative [13]

This paper will address the creation of E-Portfolio program, or course component, in terms of four phases: 1) Needs Assessment; 2) Design and Development; 3) Implementation; and 4) Evaluation. In the following sections, each of these phases will focus on important questions that all instructors, course designers, and administrators need to consider as they move forward with E-Portfolios in their courses and programs.

\section{NeEds Assessment Phase}

As one starts working with the design and development of E-Portfolio, a needs assessment should be conducted. Following the research phase of the needs assessment, it is important to focus on the intended components of the E-Portfolio to be used in the proposed course. The following section will discuss the components considered in the e-Portfolio project.

\section{E-PORTFOLIO COMPONENTS}

In the undergraduate Senior Seminar, students were asked to construct their final E-Portfolio with the following elements:

- Resume (standard or virtual resume)

- Cover Letter

- Web page (creation of a potential business idea)

- Brochure (business)

- Business Plan (planning a potential business venture) 
- Reflective Essay

- Design and Development

The course designer reviewed the Senior Seminar course description and learning objectives. This helped to serve as a basis for creating this particular course for all finishing undergraduate seniors. Once the components of the e-Portfolio were identified, the design and development phase was considered the most critical step.

\section{The Design \& DeVElopment Phase}

During the Design and Development Process, the course designer and instructor focused on the development of an 8 -week online course to help prepare senior (undergraduate) students to create their own e-Portfolio. Instead of focusing on works from other courses, it was decided to focus on assignment, which could help the student in his or her career development endeavors. In particular, the assignments were created from the learning objectives of the core courses in the Business Administration program.

It was decided that the current educational online software program, Educator, was to be utilized in the creation and implementation of the E-Portfolio assignments to be required for the course. Discussion boards were created to help encourage students to discuss the development of each assignment, as well as to help guide them through the portfolio process. After the development of these various learning activities, the next step was to focus on the implementation of the e-Portfolio component into the Senior Seminar.

\section{IMPLEMENTATION PHASE}

During the Implementation Phase, there were some considerations that needed to be addressed prior to the launching of this course. First, who will be in charge of the implementation phase? The instructor, who was also the course designer, was appointed at the lead instructor for this course in charge of all course design and implementation issues. Second, it was decided that there would be a need for documentation of the course effectiveness. Third, the question of whether there should be monitoring or reporting device was considered important, but the final decision was to allow the University's current course evaluation survey to service as the key reporting instrument. Meanwhile, the instructor would record observations and feedback gained by students during each term to be later discussed with the Dean.

Another consideration was to rest with the instructor whether he or she would require students to place all work within a self-created webpage or electronic portal or to just submit the assignments individually. It was determined by the instructor, after several course offerings, that the majority of the students were eager to place (link) their course assignments to a self-created webpage. In fact, some students went a step further and created elaborate web pages and/or electronic portals to display their work for the course (or future employers).

\section{Evaluation Phase}

As noted before, it was decided that the current University's course evaluation survey would serve as the primary evaluation tool. However, for course audits and reviews, the individual E-Portfolios would serve as the primary assessment tools. Also, many universities are using E-Portfolios for course assessment and for accreditation purposes. After several course offerings of the course, the researcher (instructor) has seen an increase in the enrollment. In fact, some students have reported back to the instructor that they have been emailing future employers with their web page URL address for the potential employer to review their e-Portfolio (capstone) presentation. Other students have noted that they have downloaded their e-Portfolio onto USB drives to carry with them as they venture out on upcoming interviews to display their academic work product to potential employers. For purposes of this paper, discussion of the evaluation process was limited in scope.

\section{CONCLusion}

While technology has increased the possibility of more students to participate in taking online courses, in light of various family, business, and personal constraints, changes still need to be done in terms of embracing diversity in education in terms of meeting the needs of our students. Thus, educators need to be proactive in making appropriate changes in the curriculum to help strengthen course offerings, as well as incorporating teaching strategies and technique that meet the needs of the course objectives, as well as motivating and encouraging the adult learners to want to learn even more. We need to continue to nurture and guide our learners as they pursue academic and career developmental endeavors.

\section{REFERENCES}

[1] L. Neal and D. Miller, "The basics of e-learning: An excerpt from Handbook of Human Factors in Web Design," para. 4-5. In R.W. Proctor \& K.L. Vu (2004), Handbook of Human Factors in Web Design, Lawrence Erlbaum Associates. Retrieved March 19, 2008 from http://www.elearnmag.org/subpage.cfm? section=tutorials\&article $=20-1$.

[2] L. Neal and D. Miller (2006), The basics of e-learning: An excerpt from Handbook of Human Factors in Web Design, para. 4-5. In R.W. Proctor \& K.L. Vu (2004), Handbook of Human Factors in Web Design, Lawrence Erlbaum Associates. Retrieved March 19, 2008 from http://www.elearnmag.org/subpage.cfm? section $=$ tutorials \&article $=20-1$.

[3] U.S. Department of Education (2008). E-Learning: Putting a world-class education at the fingertips of all children. Retrieved on March 16, 2008 from

http://www.ed.gov//about/offices/list/os/technology/reports/e-learning .html.

[4] U.S. Department of Education (2008). E-Learning: Putting a world-class education at the fingertips of all children. Retrieved on March 16, 2008 from

http://www.ed.gov//about/offices/list/os/technology/reports/e-learning .html.

[5] U.S. Department of Education (2008). E-Learning: Putting a world-class education at the fingertips of all children. Retrieved on March 16, 2008 from

http://www.ed.gov//about/offices/list/os/technology/reports/e-learning .html. 
[6] Allen, I.E., \& Seaman, J. (2008). Staying the course: Online education in the United States, 2008. The Sloan Consortium. Retrieved July 2, 2009 , from

http:www.sloan-consortium.org/publications/survey/pdf/staying_the_ course.pdf.

[7] Thompson, J.W. (1995). The renaissance of learning in business. In S Chawla and J. Renesch (1995). Learning organizations: Developing cultures for tomorrow's workplace. Portland, Oregon: Productivity Press.

[8] LDP e-Portfolio Report http://bearlink.berkeley.edu/ ePortfolio/page5.html (retrieved 6/1/2008).

[9] Greenberg (2004). In John DiMarco (2006). Web Portfolio Design and Applications. Idea Group Inc. pp. 607-608. (retrieved 6/1/2008).

[10] Greenberg (2004). In John DiMarco (2006). Web Portfolio Design and Applications. Idea Group Inc. pp. 607-608. (retrieved 6/1/2008)

[11] LDP e-Portfolio Report http://bearlink.berkeley.edu/ ePortfolio/page5.html (retrieved 6/1/2008).

[12] LDP e-Portfolio Report http://bearlink.berkeley.edu/ ePortfolio/page5.html (retrieved 6/1/2008).

[13] Job Outlook 2003, National Association of Colleges and Employers Survey.

Dr. Bob Barrett, Jr. holds an Ed.D. in the field of Human Resource Development, from The George Washington University,Washington, DC,
USA. He is a Professor in the School of Business at the American Public University, as well as an Adjunct Assistant Professor for the University of Maryland University College, Professor for Strayer University, and Instructor for Central Texas University, Central Michigan University, Franklin University, Baker College, NOVA Southeastern University, University of California - Los Angeles. His recent publications include: Barrett, B. (2011). "Developing and Implementing Strategies to Enhance Intellectual Capital in the Online Learning Environment" in the Electronic Journal of Knowledge Management, published by International Academic Conferences. Barrett, B. (2010). "Virtual Teaching and Strategies: Transitioning From Teaching Traditional Classes to Online Classes" in Contemporary Issues in Education Research. Vol. 3 (12), CLUTE Institute. ISSN 1940-5847 (Print) ISSN: 1941-756X (Online). Barrett, B. (2010) "Evaluating and Implementing Teaching Standards: Providing Quality Online Teaching Strategies and Techniques Standards." Developing and Utilizing E-Learning Applications. IGI Publishing: Hershey, PA. Dr. Barrett belongs to the Society of Human Resource Management (SHRM); D.C. Chapter - American Society of Training and Development (DC-ASTD); Alumni Association of The George Washington University; Academy of Management; National Federation for the Blind; PHI DELTA KAPPA (International Honor Fraternity); Strategic Management Society (SMS); United States Distance Learning Association (USDLA) and; Association of the United States Army (AUSA). 